\title{
Credit for Coining Terms
}

To the Editor:

It is pleasant to be given credit for one's work, but it is contrary to my personal and professional values to get credit for what I have not done.

Ken Vincent's review of Michael Perry's Psychical and spiritual: Parapsychology in Christian faith and life (Vincent, 2003), credited me with coining the term "scientism." I wish I had, since this kind of arrogant ossification of scientific theories is an important pathology of thought and perversion of real science, a pathology that harms a lot of people by apparently invalidating many of their spiritual experiences. But sociologists had noticed this phenomenon and coined the term long before I was born (see, for example, Hobb, 1910).

Similarly, I am often credited with coining the term "altered states of consciousness" because of the popularity of my book of that title (Tart, 1969), but I took the book title from a review article of that title by Arnold Ludwig (1969) that I reprinted in the book. The success of the book helped popularize the phrase, but I did not coin it.

Readers of this journal will also be interested in the fact that I have coined the slowly spreading technical terms "consensus consciousness" to emphasize the cultural determinants and relativity of so-called normal consciousness, and "consensus trance" when emphasizing the narrowness and limitations of consensus consciousness. I also coined the phrase "out-of-the-body experience" and its abbreviation "OBE." Originally I used the abbreviation "OOBE," but a grammatically rigorous editor reminded me that we do not capitalize "of" in an acronym, so it has been "OBE" ever since-which was a good thing, as I had already experienced much "semantic karma" as a result of OOBE, as people came up to me after lectures and told me about their OOBEs (rhymes with boobies), pronouncing it as if it were a word! 


\section{References}

Hobb, A. (1910). Social problems and scientism. Harrisburg, PA: Stackpole.

Ludwig, A. (1969) Altered states of consciousness. In C. T. Tart (ed.), Altered states of consciousness: A book of readings (pp. 9-22). New York, NY: Wiley.

Tart, C. T. (Ed.). (1969). Altered states of consciousness: A book of readings. New York, NY: Wiley.

Vincent, K. (2003). [Review of Psychical and spiritual: Parapsychology in Christian faith and life]. Journal of Near-Death Studies, 22, 145-148.

Charles T. Tart, Ph.D.

Professor Emeritus of Psychology University of California, Davis

Professor, Institute of Transpersonal Psychology

1069 East Meadow Circle

Palo Alto, CA 94303

E-mail: cttart@ucdavis.edu 